\title{
Comparing camera traps and visual encounter surveys for monitoring small animals
}

\author{
MADISON K. BOYNTON ${ }^{1}$, MATTHEW TOENIES ${ }^{1}$, NICOLE COR- \\ NELIUS ${ }^{1}$, AND LINDSEY N. RICH ${ }^{1}$
}

${ }^{1}$ California Department of Fish and Wildlife, Wildlife Branch, 1010 Riverside Parkway, West Sacramento, CA 95605, USA

*Corresponding Author: madison.boynton@wildlife.ca.gov

Amphibian and reptile species face numerous threats including disease, habitat loss and degradation, invasive species, and global climate change. However, effective management and conservation of herpetofauna largely depends upon resource-intensive survey methodologies. Recent research has shown promise in the use of camera trapping techniques, but these methods must be tested alongside traditional methods to fully understand their advantages and disadvantages. To meet this research need, we tested two herpetofauna survey methods: a modified version of the Adapted-Hunt Drift Fence Technique, which combines a drift fence with camera traps; and a traditional method of visual encounter surveys (VES) with cover boards. Between June and August 2020, we conducted two VES and installed one drift fence with camera traps at ten sites in Monterey County, CA, USA. The drift fence/camera setup outperformed the VES in terms of number of observations and herpetofauna species detected. Drift fences with cameras produced a mean of 248 images of three to six species per site, while VES and cover objects produced a mean of 0.6 observations of zero to one species per site. Across all sites, we detected seven reptile and one amphibian species with the drift fence/camera setup, while VES resulted in identifications of two reptile and one amphibian species. In addition, drift fence/camera setups recorded a minimum of nine nonherpetofauna species including small mammals, birds, and invertebrates. Our research supports that drift fences combined with camera traps offer an effective alternative to VES for large-scale, multi-species herpetofauna survey efforts. Furthermore, we suggest specific improvements to enhance this method's performance, cost-effectiveness, and utility in remote environments. These advances in survey methods hold great promise for aiding efforts to manage and conserve global herpetofauna diversity.

Las especies de anfibios y reptiles se enfrentan a numerosas amenazas, incluyendo enfermedades, pérdida y degradación del hábitat, especies invasoras y cambio climático global. Sin embargo, el manejo efectivo y la 
conservación de la herpetofauna depende en gran medida de metodologías de encuestas que requieren muchos recursos. Investigaciones recientes han demostrado ser prometedoras en el uso de técnicas de fototrampeo, pero estos métodos deben ser probados junto con los métodos tradicionales para comprender completamente sus ventajas y desventajas. Para satisfacer esta necesidad de investigación, probamos dos métodos de encuesta de herpetofauna: una versión modificada de Adapted-Hunt Drift Fence Technique, que combina una valla de desvío con cámaras de fototrampeo; y un método tradicional de inspección por encuentro visual (IEV) con tableros de cubierta. Entre junio y agosto del año 2020, llevamos a cabo dos IEV e instalamos una valla de desvío con cámaras en diez ubicaciones en el condado de Monterey, CA, EE. UU. La configuración de la valla de desvío/cámara superó al IEV en términos de número de observaciones y especies herpetofauna detectadas. Las vallas de desvío con cámaras produjeron una media de 248 imágenes de tres a seis especies por ubicación, mientras que el IEV y los objetos de cubierta produjeron una media de 0.6 observaciones de cero a una especie por ubicación. A través de todas las ubicaciones, detectamos siete especies de reptiles y una especie de anfibios con la configuración de la valla de desvío/cámara, mientras que el IEV resultó en identificaciones de dos especies de reptiles y una especie de anfibios. Además, las configuraciones de la cámara de la valla de desvío registraron un mínimo de nueve especies no herpetofaunas, incluyendo pequeños mamíferos, aves e invertebrados. Nuestra investigación apoya que las vallas de desvío combinadas con cámaras de fototrampeo ofrecen una alternativa efectiva a IEV para los esfuerzos de encuesta de herpetofauna a gran escala y de múltiples especies. Además, sugerimos mejoras específicas para incrementar el rendimiento, la rentabilidad y la utilidad de este método en entornos remotos. Estos avances en los métodos de encuestas son muy prometedores para ayudar a los esfuerzos de manejo y conservación de la diversidad mundial de herpetofauna.

Key words: amphibian, camera trap, cover object, drift fence, herpetofauna, invertebrate, reptile, small mammal, visual encounter survey

Reptiles and amphibians are of conservation concern due to their role as indicator species (Welsh and Ollivier 1998), susceptibility to pathogens (Phillott et al. 2010), and sensitivity to global climate change (Graeter et al. 2013). However, managing and conserving these species is challenging due to their cryptic appearance and elusive behavior (Lovich and Gibbons 1997; Fisher et al. 2008). Further, surveying for reptiles and amphibians tends to be time-intensive as most survey techniques rely on direct observations (Crump and Scott 1994; Graeter et al. 2013).

Traditional herpetofauna monitoring approaches have centered on area- or time-based visual encounter surveys (VES; Graeter et al. 2013), in which researchers physically scan an area and record information about the individuals observed (Crump and Scott 1994). The results are commonly used to assess the composition of herpetofauna communities and to estimate relative abundance for observed species (Crump and Scott 1994; Welsh et al. 2006; 
Furnas et al. 2019). VES may incorporate artificial cover objects which, by mimicking natural cover objects (e.g., logs, woody debris, rocks), encourage reptiles and amphibians to seek shelter in a location easily examinable by researchers during a future VES (Parmelee and Fitch 1995; Hampton 2007; Graeter et al. 2013). Cover objects are typically made of wood or corrugated metal, and these two object types can sample different species assemblages (Hampton 2007). Researchers and managers have been implementing these approaches for close to 40 years, but they suffer several limitations including high observer bias (Crump and Forstner 2019; Lardner et al. 2019), challenges with species identification, and extensive staff time requirements (Graeter et al. 2013).

Researchers have also sampled reptiles and amphibians using a drift fence combined with one or more pitfall traps (Fisher et al. 2008). With this method, short fences intersect an animal's path and redirect the animal toward a discreet underground container (i.e., pitfall trap) along the fence. Researchers then return to collect and identify species that have fallen into the traps. While drift fences combined with pitfall traps offer close-range visualization and biological sampling opportunity, they often result in death or unintended capture myopathy (Sikes et al. 2011; McCleery et al. 2014), risk disease spread (Daszak et al. 2003; Phillott et al. 2010), and require extensive staff resources (e.g., checking traps daily for the survey period; Fisher et al. 2008).

Recently, new approaches have been developed that allow scientists to use camera traps in lieu of pitfall traps to sample herpetofauna (McCleery et al. 2014; Hobbs and Brehme 2017; Martin et al. 2017; Amber et al. 2021). Historically, autonomously triggered camera traps struggled to detect ectotherms via infrared radiation, given their body temperatures match the environment (McCleery et al. 2014; Hobbs and Brehme 2017). Further, many species are small and move quickly so the camera triggers too late. However, recent research and advances in camera trap technology hold great promise for applying camera trapping techniques to herpetofauna.

For example, Martin et al. (2017) developed the Adapted-Hunt Drift Fence Technique (AHDriFT), which combines previous trap designs (Welbourne 2013; McCleery et al. 2014) with traditional drift fence methods. Combining drift fences with autonomously triggered camera traps may function as an effective approach for continuously collecting information on reptile and amphibian species while minimizing the limitations associated with VES, cover boards, and pitfall traps (e.g., observer disturbance and bias; Crump and Forstner 2019).

Our goal was to evaluate the efficacy of visual encounter surveys with cover objects as compared to drift fences with camera traps for detecting reptile and amphibian species. To do this, we compared the number of species and taxonomic groups observed using each method. Secondarily, we sought to explore the design of the drift fence/camera setup, with the goal of developing the most logistically feasible approach possible. Our study will help researchers and conservation managers of diverse projects choose the optimal field method to survey herpetofauna.

\section{METHODS}

\section{Study Area}

Our fieldwork was carried out in Hastings Natural History Reservation in Monterey County, California, USA $(36.380,-121.564)$. The $9.5-\mathrm{km}^{2}$ reserve is primarily composed of oak woodlands (Quercus spp.) and chaparral (Griffin 1990). Mean annual temperature and precipitation are $13.4^{\circ} \mathrm{C}$ and $522 \mathrm{~mm}$, respectively (McMahon et al. 2015). 


\section{Data Collection}

Artificial cover objects and visual encounter surveys.-We conducted field work from 17 June to 08 August 2020, at 10 sites spaced by at least $500 \mathrm{~m}$. At each site, we deployed artificial cover objects at the corners of a $25-\mathrm{m} \times 25-\mathrm{m}$ quadrat (Fig. 1). Two of the cover objects were wooden boards $(61-\mathrm{cm} \times 61-\mathrm{cm}$ sections of oriented strand board) and the other two were metal sheets $(61-\mathrm{cm} \times 61-\mathrm{cm}$ sections of $1.3-\mathrm{cm} 26$-gauge corrugated metal). Reptiles and amphibians may vary in the temperature conditions under which they are effectively sampled by cover objects (Graeter et al. 2013). Therefore, in cases where the four quadrat corners differed in their levels of sun exposure, we deployed one metal and one wooden cover object in the two sunniest locations, and one of each type in the two shadiest locations. Where there were no sun/shade differences, we alternated placement of cover object types. We also scraped away the litter/vegetation under one metal and one wood cover object prior to placement, as clearing the space under a cover object may reduce snake use but enhance use by some amphibians (Parmelee and Fitch 1995; Graeter et al. 2013). At sites within $50 \mathrm{~m}$ of a waterway, we placed artificial cover objects every $25 \mathrm{~m}$ along the margin of the waterway (rather than in a $25-\mathrm{m}^{2}$ quadrat) while still accommodating the sun/ shade and vegetation/scraped specifications.

We conducted VES within the quadrats or along the transects (for sites adjacent to waterways) following the methods of Crump and Scott (1994). Surveys lasted a minimum of 10 minutes, but search time varied depending on the complexity of the habitat (e.g., wooded habitats with many natural cover objects took longer to survey). We conducted two surveys per site approximately 46.5 days apart. Whenever possible, we attempted to conduct surveys before ambient temperatures reached $26^{\circ} \mathrm{C}$ as many species leave cover objects to forage at hotter temperatures (Stevenson 1985; Joppa et al. 2010). We collected site metadata and VES observations using Survey123 Connect (Environmental Systems Research Institute, Inc., Redlands, CA, USA) digital datasheets.

Drift fence with camera traps. - We also installed one drift fence/camera trap setup at each of the 10 sites during the same survey period as the VES. To ensure that both survey

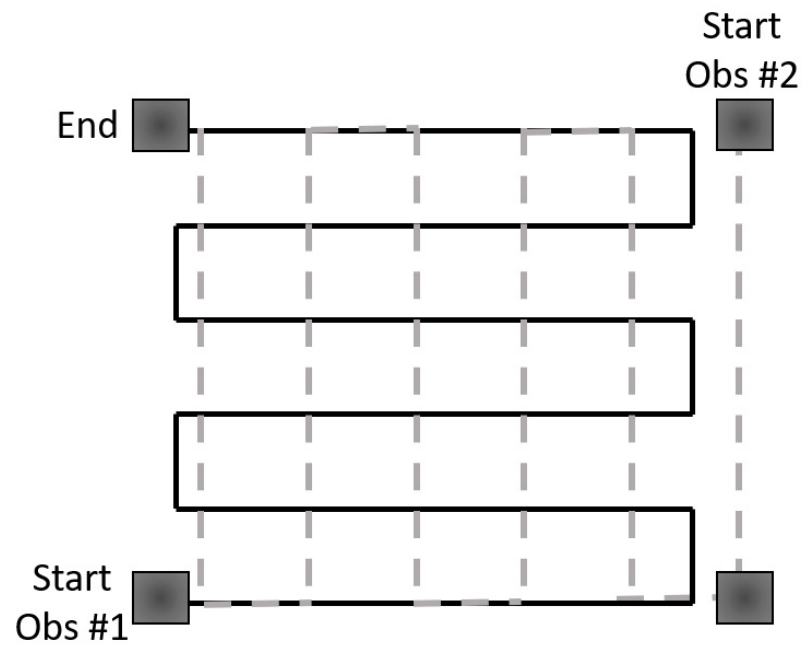

Figure 1. Diagram of a visual encounter survey quadrat, where cover objects mark the corners of the $25-\mathrm{m}^{2}$ quadrat and lines indicate paths walked by two human observers. 
methods were sampling the same species assemblages, we deployed the drift fence/camera trap setup within the associated VES plot or for sites adjacent to waterways, overlaying or immediately adjacent to the VES transect. Following recommendations from Fisher et al. (2008), we installed a 7-m silt drift fence crossing a likely terrestrial movement corridor, such as a habitat edge, ravine, or route to an aquatic feature (Fig. 2). Next, we installed a camera trap structure at each end of the drift fence (Fig. 2). We designed the structures following the methodology of Martin et al. (2017), with some minor modifications. Specifically, 1) we used the natural ground as the base to our structures instead of artificial flooring, 2) some of our structures were larger (18.9-26.5 L) than those of Martin et al. (2017) so that they would accommodate our camera focal distances, and 3) we added live mealworm bait, which was contained within a metal tea infuser ball staked to the ground, to half of our structures. The metal tea infuser ball inhibited bait removal so that a constant olfactory attractant and (until mealworm death) auditory cue were available to target species (Tennant et al. 2017). We used Hyperfire $2 \mathrm{HP} 2 \mathrm{X}$ cameras, which had a factory-set focal distance of $50 \mathrm{~cm}$ to approximate the height of our buckets (Reconyx, Holmen, WI, USA; Tennant et al. 2017). We programmed cameras to take three photos at each trigger event, with high sensitivity and no delay between trigger events (detailed settings in Appendix 1). We positioned cameras so the infrared sensor was closer to the bucket entrance than the lens was, thus causing animals to trigger the sensor before passing in front of the lens (Welbourne 2013). Cameras were deployed for 44-48 $(\bar{x}=46.5)$ days.

\section{Data Processing and Analysis}

We organized camera trap images and extracted image metadata (e.g., time and date of photo) using the camtrapR package (Niedballa et al. 2016) in RStudio (RStudio v. 1.3.1073, www.rstudio.com, accessed 15 Oct 2020). We then manually identified each photo to species or to a higher-level taxon when species identification was not possible. A second person then manually reviewed all herpetofauna images to validate species identifications and to refine higher-level taxon identifications to species identifications. We did not have
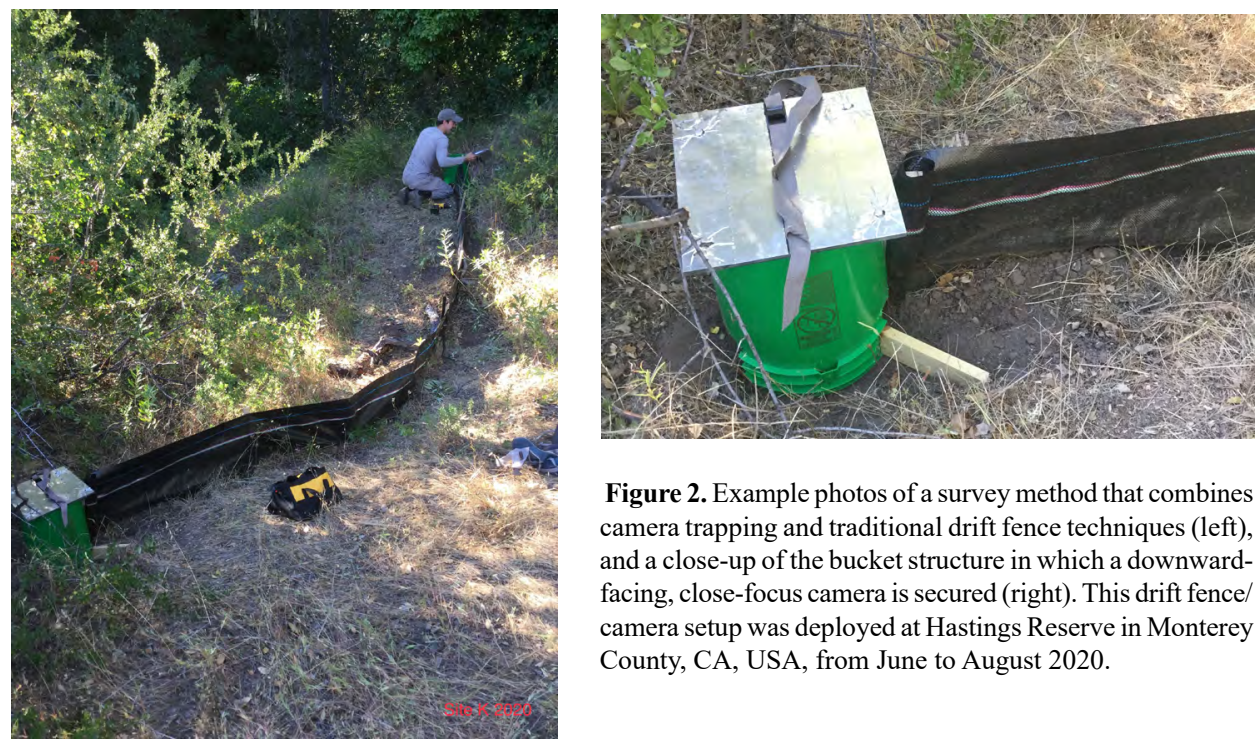

Figure 2. Example photos of a survey method that combines camera trapping and traditional drift fence techniques (left), and a close-up of the bucket structure in which a downwardfacing, close-focus camera is secured (right). This drift fence/ camera setup was deployed at Hastings Reserve in Monterey County, CA, USA, from June to August 2020. 
a second person review non-herpetofauna images given our primary focus was sampling reptiles and amphibians. We made species identifications in the field for VES. Thus, VES data processing only involved exporting datasheets from Survey123.

We then analyzed the tabulated data. We determined the number of species and taxonomic groups detected by each method for the full survey period. We further compared site-level detections at camera traps with and without bait, as well as at one versus both camera traps.

\section{RESULTS}

\section{Comparison between Survey Methods}

We detected a minimum of 18 animal species across all sites and methods including seven reptiles, two amphibians, six mammals, two birds, and at least one invertebrate species (Fig. 3; Tables 1, 2). We refer to minimum numbers of species due to some nonherpetofauna identifications only being possible at the level of family or order. The her-
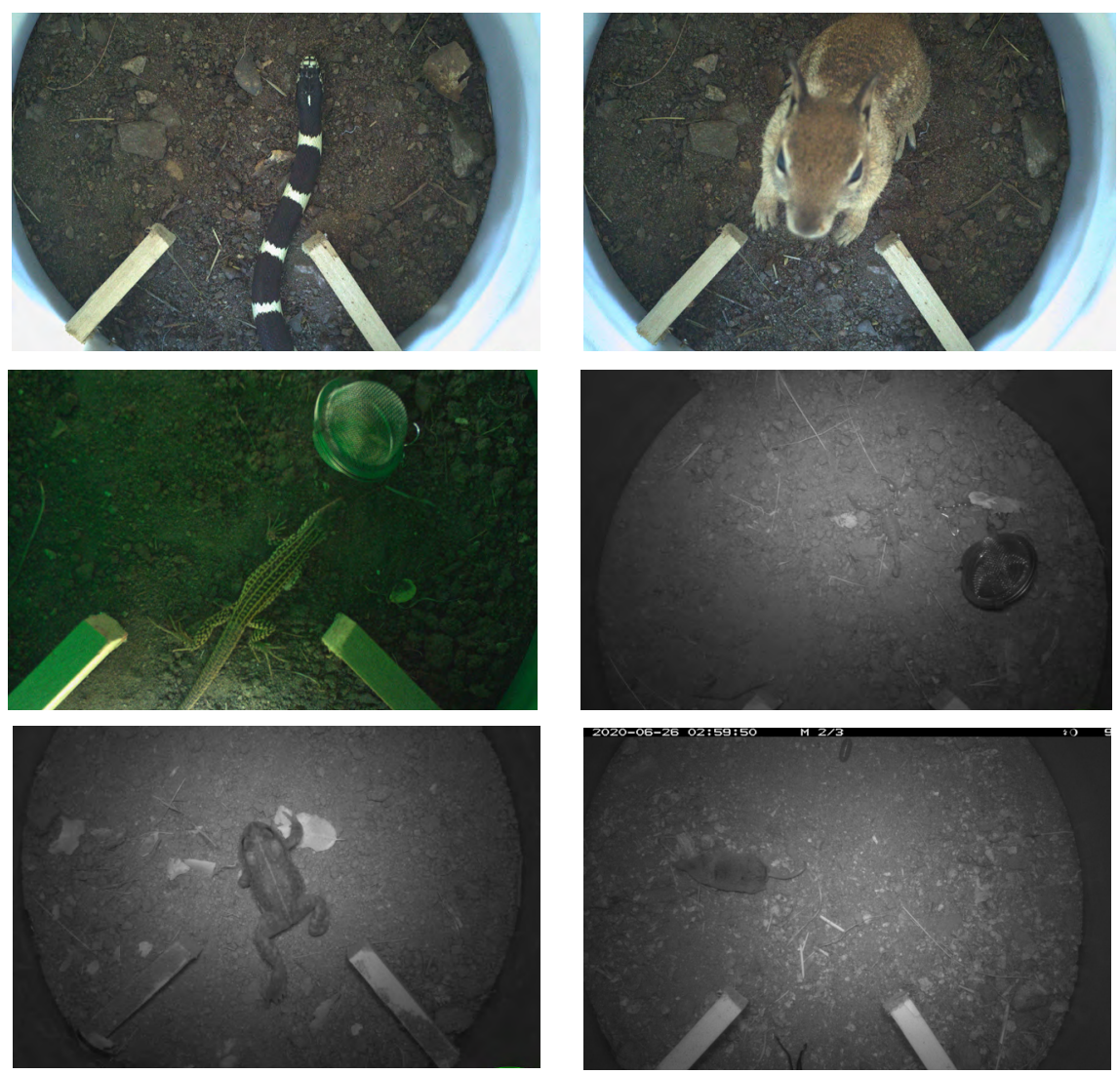

Figure 3. Moving left to right and top to bottom, camera trap images of a A) California kingsnake (Lampropeltis californiae), B) western whiptail (Aspidoscelis tigris), C) western toad (Anaxyrus boreas), D) California ground squirrel (Otospermophilus beecheyi), E) invertebrate, and F) shrew (Soricidae sp.). These images were captured using a survey method that combines camera trapping and traditional drift fence techniques. We deployed this survey method at Hastings Reserve in Monterey County, CA, USA, from June to August 2020. 
petofauna we detected at the most sites using the drift fence/camera setup were western skink (Plestiodon skiltonianus, $\mathrm{n}=10$ ) and western fence lizard (Sceloporus occidentalis, $\mathrm{n}=10$ ). Western fence lizard was also the species identified at the most sites using VES/ cover objects $(n=3)$. We identified six herpetofauna species using the drift fence/camera setup that we did not identify using VES/cover objects including three species of snake, two species of lizard, and western toad (Anaxyrus boreas, Table 1). We identified one species (ensatina [Ensatina escholtzii]) using VES/cover objects that we did not identify using the drift fence/camera setup.

We recorded more detections and species with the drift fence/camera setup than with VES/cover objects on both a per-site and full survey period basis. Across all sites and the full survey season, we observed a minimum of three species of reptiles and amphibians with the VES/cover objects and eight species of reptiles and amphibians with the drift fence/camera traps (Table 1). From the VES/cover objects, we had a mean of 0.6 detections per survey (range $=0-5$ ) of zero to one identifiable species of herpetofauna. We did not detect any reptile or amphibian species during $60 \%$ of our VES. We made several VES observations under natural cover objects but found no individuals at the artificial cover objects. In comparison, the drift fence/camera setup produced a mean of 247.85 herpetofauna images per site (range $=34-1241$ ), with a mean of 4.2 species of herpetofauna (range $=3-6$ ) detected per site.

The drift fence/camera setup had the added benefit of producing many images of non-herpetofauna species with over two-thirds of the images being of mammals, birds, or invertebrates (Table 2; Fig. 4). Specifically, we detected a minimum of six mammal, two bird, and an unknown number of invertebrate species with the camera traps (Table 2). As mentioned above, we refer to minimum numbers of species due to some non-herpetofauna identifications only being possible at the level of family, order, or class. All cameras captured mammals, and all but one also captured invertebrates (Table 2). Unidentified rodents (order Rodentia) and mice (Peromyscus spp.) were the most photographed non-herpetofauna taxa. Only $14.8 \%$ of the camera trap images were blank (i.e., non-animal, non-researcher photos;

Table 1. The number of sites (\# sites; $n=10$ ) at which reptiles and amphibians were observed via two field methods. The first combined a drift fence with two close-focus camera traps (drift fence/camera) and the second was a visual encounter survey with artificial cover objects (VES/cover object). Sites were located at Hastings Reserve, Monterey County, CA, USA, and surveyed between June and August 2020.

\begin{tabular}{lllcc}
\hline Group & Species & Common name & \multicolumn{2}{c}{ \# sites } \\
\cline { 3 - 5 } & & & $\begin{array}{c}\text { Drift fence/ } \\
\text { camera }\end{array}$ & $\begin{array}{c}\text { VES } / \text { cover } \\
\text { object }\end{array}$ \\
\hline \multirow{2}{*}{ Reptiles } & Squamata & lizard order & 0 & 2 \\
& Lampropeltis californiae & California kingsnake & 4 & 0 \\
& Coluber lateralis & striped racer & 6 & 0 \\
& Aspidoscelis tigris & western whiptail & 7 & 1 \\
& Plestiodon skiltonianus & western skink & 10 & 0 \\
& Elgaria multicarinata & southern alligator lizard & 1 & 0 \\
& Sceloporus occidentalis & western fence lizard & 10 & 3 \\
& Coluber constrictor & North American racer & 2 & 0 \\
\hline & Anaxyrus boreas & western toad & 2 & 0 \\
& Ensatina eschscholtzii & ensatina & 0 & 1 \\
\hline
\end{tabular}


Table 2. The number of sites (\# Sites; $n=10$ ) at which taxa were observed using a drift fence in combination with close-focus camera traps and the total number of images of each taxa (\# Images). This study targeted herpetofauna, so other taxa were infrequently identified to species level. Sites were located at Hastings Reserve, Monterey County, CA, USA, and surveyed between June and August 2020.

\begin{tabular}{lllrr}
\hline Taxon & Scientific name & Common name & \# Sites & \# Images \\
\hline Reptiles & Lampropeltis californiae & California kingsnake & 4 & 36 \\
& Coluber lateralis & striped racer & 6 & 28 \\
& Aspidoscelis tigris & western whiptail & 7 & 3,399 \\
& Plestiodon skiltonianus & western skink & 10 & 346 \\
& Elgaria multicarinata & southern alligator lizard & 1 & 8 \\
& Sceloporus occidentalis & western fence lizard & 10 & 1,116 \\
& Coluber constrictor & North American racer & 2 & 6 \\
Amphibians & Anaxyrus boreas & western toad & 2 & 18 \\
& Rodentia & rodent order & 10 & 6,300 \\
& Dipodomys sp. & kangaroo rat sp. & 1 & 34 \\
& Peromyscus sp. & mouse sp. & 7 & 2173 \\
& Soricidae sp. & shrew sp. & 5 & 154 \\
& Sylvilagus bachmani & brush rabbit & 1 & 60 \\
& Otospermophilus beecheyi & California ground squirrel & 3 & 803 \\
& Mephitis mephitis & striped skunk & 7 & 364 \\
& Oreortyx pictus & mountain quail & 1 & 147 \\
& Aphelocoma californica & western scrub-jay & 1 & 6 \\
& & & 10 & 293 \\
\hline
\end{tabular}

Table 3), and many of these blank images were instances where the species moved out of the image frame after the first photo was taken (i.e., first image in the trigger event included the animal and the following two images were blank).

\section{Drift Fence/Camera Setup Improvements}

One camera versus two cameras per fence. - Comparisons of herpetofauna detections between pairs of cameras showed that, within individual 24-hour periods, a mean of $46 \%$ of species records were captured at both cameras, while $54 \%$ were captured at a single camera (Table 4). When compared across the entire survey period, the mean proportions of species records shifted to $71 \%$ at both cameras and $29 \%$ at a single camera. Across the entire survey period, southern alligator lizard (Elgaria multicarinata) was the only herpetofauna species detected at one camera within a pair, while fence lizard and western whiptail (Aspidoscelis tigris) were always detected at both cameras.

Baited versus non-baited camera traps.-Baited and non-baited structures did not show statistically significant differences (i.e., 95\% confidence intervals overlapped) in the numbers of images captured across all taxa or for herpetofauna species. Across all taxa, baited and non-baited structures recorded a mean of 746.3 and 824.1 images, respectively. Across only reptiles and amphibians, baited bucket structures recorded a mean of 266.8 images 


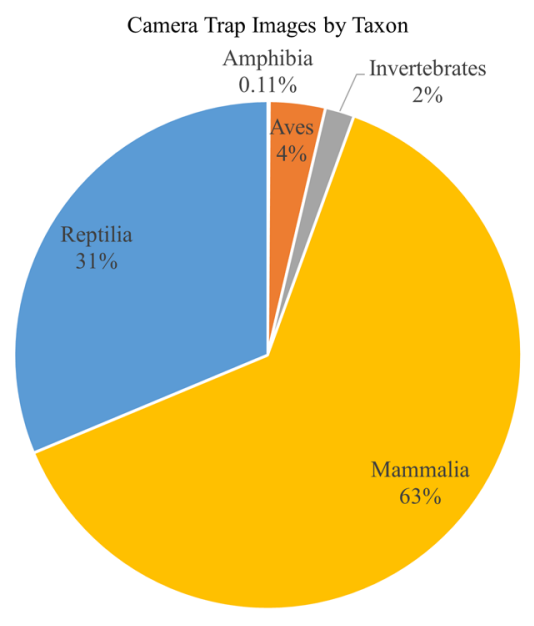

Figure 4. Taxa detected using a survey method that combines camera trapping and traditional drift fence techniques. We deployed this method at Hastings Reserve, Monterey, CA, USA from June to August 2020.

and 3.7 species while non-baited bucket structures recorded a mean of 228.9 images and 3.5 species (Table 3). Southern alligator lizard was the only species photographed at one baited camera and no non-baited cameras. In addition, three cameras captured western toad; two baited cameras recorded a combined total of 16 toad photos while one non-baited camera recorded two photos. These results indicate that bait did not increase total detections across all taxa, but it may have increased our probability of photographing some herpetofauna.

\section{DISCUSSION}

The drift fence combined with camera traps recorded up to five more species and over 400 times as many observations of reptiles and amphibians than the VES and cover object method. In addition to reptiles and amphibians, it also provided information on at least nine species of birds, small to medium mammals, and invertebrates. Our study results suggest that drift fences combined with camera traps may be the preferred survey method when the goal is to maximize presence-absence information across terrestrial herpetofauna species.

The camera trap/drift fence method outperformed VES in enabling observers to confidently identify observed animals to species while also greatly reducing the potential for observer bias. One hundred percent of herpetofauna photos were identifiable to species as compared to only $58 \%$ of VES observations. Camera trap photos also allowed for secondary review of species identifications. By contrast, secondary review of VES identifications was only possible if field staff photographed observed animals with a handheld camera. Despite carrying cameras on our VES, we were unable to photograph any animals due to their speed and/or ability to quickly hide in leaf litter. The camera trap/drift fence method also eliminated biases involved in VES that can arise from variable field observer effort and observers' ability to correctly and quickly identify detected animals to species.

An additional benefit of camera traps combined with drift fences, as compared to VES, is that they capture greater species diversity. We detected at least 17 animal species with drift fences and camera traps compared to just three species with VES. This improved efficacy is due to camera traps operating 24 hours per day, as compared to VES that are typically done in the morning, meaning cameras provide information on both diurnal and nocturnal 


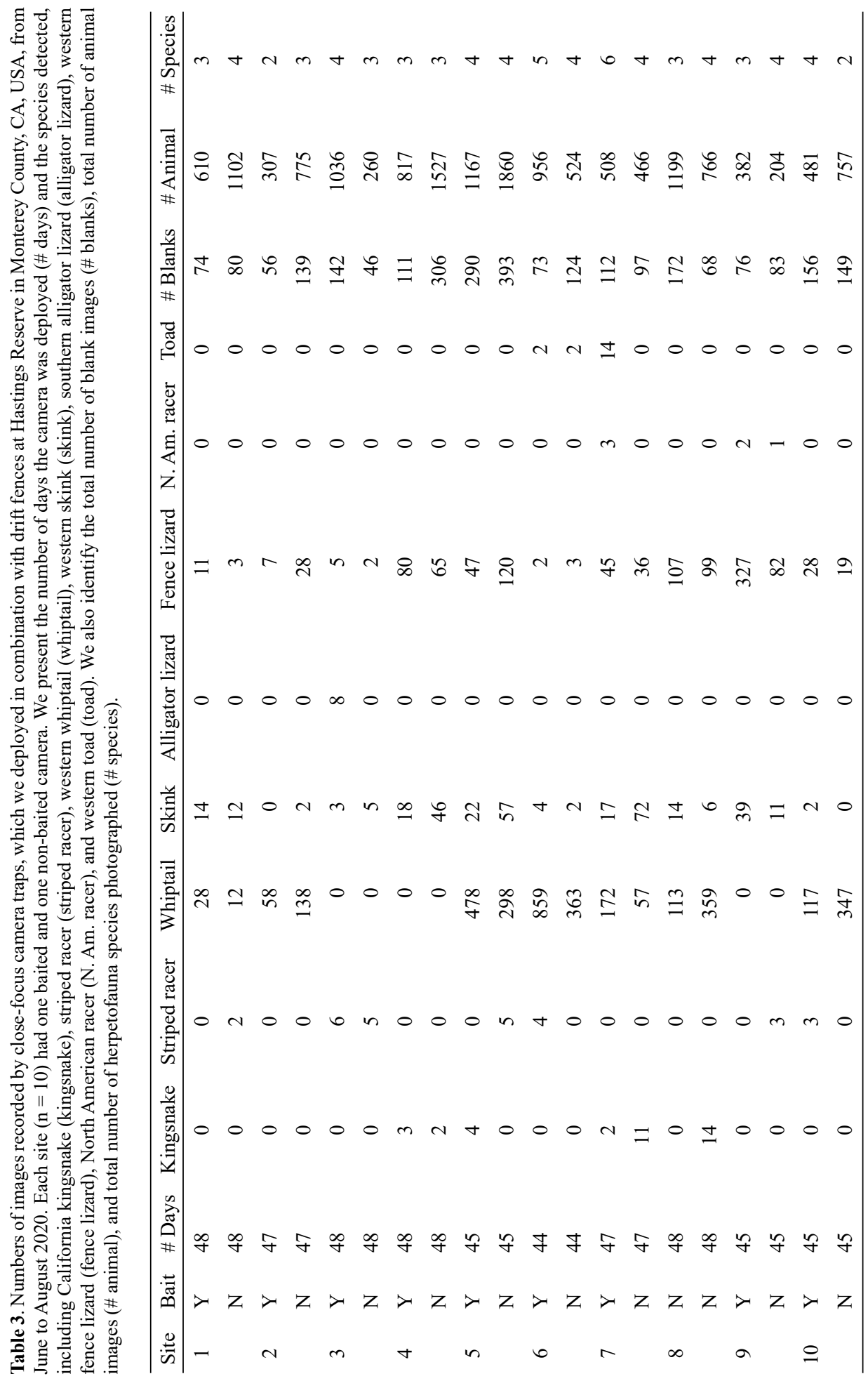


Table 4. Detections from close-focus camera traps, which were deployed in combination with a drift fence at Hastings Reserve in Monterey County, CA, USA, from June to August 2020. Each site $(n=10)$ contained two camera traps, one at either end of a drift fence. We present the number of sites at which species were photographed by one vs. two cameras (\# sites) and the number of site-days when species were photographed by one vs. two cameras (\# site-days), where site-days refer to unique combinations of sites and days for which cameras were active (similar to trap-nights).

\begin{tabular}{|c|c|c|c|c|c|c|}
\hline & \multirow[t]{2}{*}{ Scientific name } & \multirow[t]{2}{*}{ Common name } & \multicolumn{2}{|c|}{ \# Sites } & \multicolumn{2}{|c|}{ \# Site-days } \\
\hline & & & 1 camera & 2 cameras & 1 camera & 2 cameras \\
\hline \multirow[t]{7}{*}{ Reptiles } & $\begin{array}{l}\text { Lampropeltis } \\
\text { californiae }\end{array}$ & $\begin{array}{l}\text { California king- } \\
\text { snake }\end{array}$ & 2 & 2 & 9 & 0 \\
\hline & Coluber lateralis & striped racer & 5 & 1 & 9 & 1 \\
\hline & Aspidoscelis tigris & western whiptail & 0 & 7 & 108 & 92 \\
\hline & $\begin{array}{l}\text { Plestiodon skilto- } \\
\text { nianus }\end{array}$ & western skink & 2 & 8 & 79 & 12 \\
\hline & $\begin{array}{l}\text { Elgaria multicari- } \\
\text { nata }\end{array}$ & $\begin{array}{l}\text { southern alliga- } \\
\text { tor lizard }\end{array}$ & 1 & 0 & 2 & 0 \\
\hline & $\begin{array}{l}\text { Sceloporus oc- } \\
\text { cidentalis }\end{array}$ & $\begin{array}{l}\text { western fence } \\
\text { lizard }\end{array}$ & 0 & 10 & 100 & 29 \\
\hline & $\begin{array}{l}\text { Coluber constric- } \\
\text { tor }\end{array}$ & $\begin{array}{l}\text { North American } \\
\text { racer }\end{array}$ & 1 & 1 & 3 & 0 \\
\hline Amphibians & Anaxyrus boreas & western toad & 1 & 1 & 5 & 0 \\
\hline Total & & & 12 & 30 & 315 & 134 \\
\hline $\begin{array}{l}\text { Percent of } \\
\text { total }\end{array}$ & & & 28.6 & 71.4 & 70.2 & 29.8 \\
\hline
\end{tabular}

species. Further, because camera traps continuously collect information over the duration of the survey period, they are able to capture more species and more observations than is possible with VES, which require staff to be physically present. Cameras also facilitate data collection on a broader community of species given they photograph all animals that pass underneath them, as compared to VES that specifically target reptiles and amphibians. Lastly, the drift fence/camera trap method presents the opportunity to ask questions related to population abundance and density given a subset of the photographed species have uniquely identifiable markings and can be identified to individual by either computer algorithms or trained human observers with identification keys (Silver et al. 2004; Treilibs et al. 2016; Moore et al. 2020).

When compared to other camera-based methods for surveying herpetofauna, we found that our drift fence/camera method had a much lower proportion of non-target to target images. Camera trapping efforts targeting reptiles and amphibians frequently employ timelapse methodology (Gibson et al. 2015), which can demand an intensive data processing component, as it often produces a very high proportion of non-target images (Hobbs and Brehme 2017). For example, Neuharth et al. (2020) used time-lapse methods to survey snakes and reported an average of 1 target species detection per 16,038 images. Furthermore, our ratio of target to nontarget images exceeds that reported in similar studies employing the AHDriFT method (Amber et al. 2021). 
The camera trap/drift fence technique also possesses several disadvantages. Prefieldwork preparation and equipment construction require non-negligible staff time, and high-quality camera traps are expensive. In comparison, VES and artificial cover objects require little fieldwork preparation and low-cost materials. Another potential disadvantage is that cameras are only able to detect species that are moving through a landscape whereas with VES and artificial cover object surveys, researchers may have the ability to detect reptiles and amphibians that are seasonally inactive. Mitigating camera theft and vandalism is also difficult since it is challenging to lock cameras to trees or other permanent structures (due to their placement in buckets), but approaches for modifying camera structures to facilitate locking are in development (see Appendix II). Lastly, as is common in all camera trap studies, manual identification of photographed species can be a time-intensive task. However, artificial intelligence algorithms are being developed that will expedite this step by auto-classifying species and removing blank images (Ahumada et al. 2020).

We had limited detections of amphibian species using both survey methods. We had one VES observation of an ensatina and 18 photographic records of western toad across three cameras. This may be because we sampled in June and August when conditions were extremely dry and little water was available. We recommend aligning the timing of any surveys targeting amphibians, whether that be VES and/or drift fences combined with camera traps, to overlap with peak amphibian activity so that there is a higher probability of detecting these species. For example, if we had surveyed earlier in the year, we may have also detected northern pacific treefrog (Pseudacris regilla), California tiger salamander (Ambystoma californiense), and foothill yellow-legged frog (Rana boylii) which are known to be present at Hastings (Hastings Natural History Reservation 2020). Previous research has shown that similar drift fence/camera setups have successfully sampled some amphibian species when and where they are active (Martin et al. 2017; Amber et al. 2021). We recommend further investigations aimed at assessing whether the camera trap/drift fence method is effective at sampling amphibians.

Based on the results of our field surveys, we have several recommendations on how the camera trap and drift fence method may be employed most effectively. First, we detected more species from both cameras at a fence versus a single camera, although the advantage of two cameras diminished over the length of the survey period. Given a long enough survey period, researchers could use a single camera at one end of a fence, cutting camera costs in half while still producing data that meets their needs. In addition, recent research shows that drift fence turnarounds can redirect herpetofauna and small mammal movements back along fences (Brehme et al. 2020). This approach could be trialed to redirect animals toward the camera end of a fence, further reducing the need for two cameras. Second, the rigid bucket structures are difficult to carry to remote field locations. We recommend exploring more lightweight or collapsible materials, such as foldable corrugated plastic, which could be used to create "pseudo-buckets" that fit inside a pack when folded (Appendix II). Third, within the camera's field of view, we recommend clearing vegetation to prevent false triggers and securing a ruler to the ground for animal size reference (McCleery et al. 2014). Fourth, we recommend ensuring the factory-adjusted camera focal distance aligns closely with the height of the mounted camera, as we received blurry images of some animals from the shorter bucket structures. Fifth, we recommend that researchers adjust camera settings based on project goals. For example, we received sets of $100+$ photos when animals made lengthy visits to camera traps. To avoid this, time between trigger events could be set to 
greater than zero seconds. Moreover, studies that must reduce the number of images may limit trigger events to two photos per event rather than three. Finally, we encourage further study to assess the effectiveness of bait on increasing reptile and amphibian detection rates.

Our research suggests that large-scale implementation of the drift fence/camera method would improve knowledge of reptile and amphibian distributions which, in turn, would increase the ability to make informed and expedient conservation and management decisions. This is imperative given that reptiles and amphibians are facing widespread declines due to environmental contaminants, disease, invasive species, global climate change, and habitat destruction (Gibbons et al. 2000; Daszak et al. 2003; Maerz et al. 2005; Sparling 2010; Graeter et al. 2013; Ribeiro 2018). New threats to herpetofauna continue to arise, such as snake fungal disease, identified as a major conservation concern (Sutherland et al. 2014) and recently identified in California for the first time (CDFW 2019). The camera trap/ drift fence method also holds great promise as it could be expanded to address questions pertaining to population density (Martin et al. 2017; Amber et al. 2021), DNA-coded health data (Henry and Russello 2011; Martin et al. 2017), invertebrate inventorying (Zhong et al. 2018), and small animal distributions (De Bondi et al. 2010; McCleery et al. 2014; Mills et al. 2016). In addition, leaving drift fence/camera setups active across the full annual cycle could provide information on reptile and amphibian temporal activity patterns, both daily and annual, and elucidate how these patterns are influenced by natural and anthropogenic changes. Ultimately, these advances in survey methodology hold the promise of improving confidence and precision in decision-making, resulting in more effective conservation and management of herpetofauna diversity.

\section{ACKNOWLEDGMENTS}

The California Department of Fish and Wildlife funded this study as part of the California Environmental Monitoring and Assessment Framework. Our fieldwork would not have been possible without the knowledge and help of Dr. J. Hunter, Resident Reserve Director at Hastings Natural History Reservation. We also thank G. Lipps and S. Martin (Ohio State University) for their insight on the use of the AHDriFT method, G. Nafis (California Herps website) for use of herpetofauna images in our digital datasheets, and our colleagues E. Chappell, L. Patterson, and L. Souza (California Department of Fish and Wildlife) for providing critical background information on California herpetofauna and for facilitating this study. Finally, we thank M. Rodríguez (California Department of Fish and Wildlife) and A. Blasco, who provided a Spanish translation of the manuscript's abstract.

\section{LITERATURE CITED}

Ahumada, J. A., E. Fegraus, T. Birch, N. Flores, R. Kays, T. G. O’Brien, J. Palmer, S. Schuttler, J. Y. Zhao, W. Jetz, M. Kinnaird, S. Kulkarni, A. Lyet, D. Thau, M. Duong, R. Oliver, and A. Dancer. 2020. Wildlife Insights: A platform to maximize the potential of camera trap and other passive sensor wildlife data for the planet. Environmental Conservation 47(1):1-6.

Amber, E. D., G. J. Lipps, and W. E. Peterman. 2021. Evaluation of the AHDriFT camera trap system to survey for small mammals and herpetofauna. Journal of Fish and Wildlife Management 12:197-207.

Brehme, C. S., J. A. Tracey, J. Kingston, J. B. Sebes, T. K. Edgarian, and R. N. Fisher. 2020. 
Effectiveness of turnarounds in changing the trajectory of reptiles and amphibians in San Diego, CA. Pages 135-144 in Brehme, C. S. and R. N. Fisher. Research to Inform Caltrans Best Management Practices for Reptile and Amphibian Road Crossings. USGS Cooperator Report to California Department of Transportation, Division of Research, Innovation and System Information 65A0553.

California Department of Fish and Wildlife (CDFW). 2019. Snake fungal disease detected in California. Available from: https://cdfgnews.wordpress.com/2019/11/05/ snake-fungal-disease-detected-in-california/

Crump, M. L., and N. J. Scott, Jr. 1994. Visual encounter surveys. Pages 84-92 in W. R. Heyer, M. A. Donnelly, R. W. McDiarmid, L. C. Hayek, and M. S. Foster, editors. Measuring and Monitoring Biological Diversity: Standard Methods for amphibians. Smithsonian Institution Press, Washington D.C., USA.

Crump, P. S., and M. R. Forstner. 2019. Bias and precision of lizard occupancy estimates vary among observers and between methods. Journal of Herpetology 53(1)13-21.

Daszak, P., A. A. Cunningham, and A. D. Hyatt. 2003. Infectious disease and amphibian population declines. Diversity and Distributions 9:141-150.

De Bondi, N., J. G. White, M. Stevens, and R. Cooke. 2010. A comparison of the effectiveness of camera trapping and live trapping for sampling terrestrial small-mammal communities. Wildlife Research 37(6):456-465.

Fisher, R., D. Stokes, C. Rochester, C. Brehme, S. Hathaway, and T. Case. 2008. Herpetological monitoring using a pitfall trapping design in southern California. Pages 1-44 in D. Kempthorne and M. D. Myers, Secretary and Director. Collection of Environmental Data. U.S. Geological Survey Techniques and Methods.

Furnas, B. J., D. S. Newton, G. D. Capehart, and C. W. Barrows. 2019. Hierarchical distance sampling to estimate population sizes of common lizards across a desert ecoregion. Ecology and Evolution 9(6):3046-3058.

Gibbons, J. W., D. E. Scott, T. J. Ryan, K. A. Buhlmann, T. D. Tuberville, B. S. Metts, J. L. Greene, T. Mills, Y. Leiden, S. Poppy, and C. T. Winne. 2000. The global decline of reptiles, déjà vu amphibians: reptile species are declining on a global scale. Six significant threats to reptile populations are habitat loss and degradation, introduced invasive species, environmental pollution, disease, unsustainable use, and global climate change. BioScience 50(8):653-666.

Gibson, S., S. Penniket, and A. Cree. 2015. Are viviparous lizards from cool climates ever exclusively nocturnal? Evidence for extensive basking in a New Zealand gecko. Biological Journal of the Linnean Society 115:882-895.

Graeter, G. J., K. A. Buhlmann, L. R. Wilkinson, and J. W. Gibbons. 2013. Inventory and monitoring: recommended techniques for reptiles and amphibians. Partners in Amphibian and Reptile Conservation Technical Publication IM-1, Birmingham, AL, USA.

Griffin, J. R. 1990. Flora of Hastings Reservation, Carmel Valley, California. 3rd edition. University of California, Berkeley, CA, USA.

Hampton, P. 2007. A comparison of the success of artificial cover types for capturing amphibians and reptiles. Amphibia-Reptilia 28(3):433-437.

Hastings Natural History Reservation. 2020. Amphibians and Reptiles. Available from: http://hastingsreserve.org/natural-history-resources/amphibians-reptiles.html (Accessed 17 May 2021) 
Henry, P., and M. A. Russello. 2011. Obtaining high-quality DNA from elusive small mammals using low-tech hair snares. European Journal of Wildlife Research 57(3):429-435.

Hobbs, M. T., and C. S. Brehme. 2017. An improved camera trap for amphibians, reptiles, small mammals, and large invertebrates. PLoS ONE 12(10):e0185026.

Joppa, L. N., C. K. Williams, S. A. Temple, and G. S. Casper. 2010. Environmental factors affecting sampling success of artificial cover objects. Herpetological Conservation and Biology 5(1):143-148.

Lardner, B., A. A. Yackel Adams, A. J. Knox, J. A. Savidge, and R. N. Reed. 2019. Do observer fatigue and taxon bias compromise visual encounter surveys for small vertebrates? Wildlife Research 46(2):127-135.

Lovich, J. E., and J. W. Gibbons. 1997. Conservation of covert species: protecting species we don't even know. Proceedings of the New York Turtle and Tortoise Society: Conservation, Restoration, and Management of Tortoises and Turtles-An International Conference 426-429.

Maerz, J. C., C. J. Brown, C. T. Chapin, and B. Blossey. 2005. Can secondary compounds of an invasive plant affect larval amphibians? Functional Ecology 19:970-975.

Martin, S. A., R. M. Rautsaw, F. Robb, M. R. Bolt, C. L. Parkinson, and R. A. Seigel. 2017. Set AHDriFT: Applying game cameras to drift fences for surveying herpetofauna and small mammals. Wildlife Society Bulletin 41(4):804-809.

McCleery, R. A., C. L. Zweig, M. A. Desa, R. Hunt, W. M. Kitchens, and H. F. Percival. 2014. A novel method for camera-trapping small mammals. Wildlife Society Bulletin 38(4):887-891.

McMahon, D. E., I. S. Pearse, W. D. Koenig, and E. L. Walters. 2015. Tree community shifts and Acorn Woodpecker population increases over three decades in a Californian oak woodland. Canadian Journal of Forest Research 45:1113-1120.

Mills, C. A., B. J. Godley, and D. J. Hodgson. 2016. Take only photographs, leave only footprints: novel applications of non-invasive survey methods for rapid detection of small, arboreal animals. PLoS ONE 11(1):e0146142.

Moore, H. A., J. L. Champney, J. A. Dunlop, L. E. Valentine, and D. G. Nimmo. 2020. Spot on: using camera traps to individually monitor one of the world's largest lizards. Wildlife Research 47(4):326-337.

Niedballa, J., R. Sollmann, A. Courtiol, and A. Wilting. 2016. camtrapR: an R package for efficient camera trap data management. Methods in Ecology and Evolution 7(12):1457-1462.

Neuharth, D. B., W. A. Ryberg, C. S. Adams, T. J. Hibbitts, D. K. Walkup, S. L. Frizzell, T. E. Johnson, B. L. Pierce, J. B. Pierce, and D. C. Rudolph. 2020. Searching for rare and secretive snakes: are camera-trap and box-trap methods interchangeable? Wildlife Research 47(6):476-484.

Parmelee, J., and H. S. Fitch. 1995. An experiment with artificial shelters for snakes: Effects of material, age, and surface preparation. Herpetological Natural History 3(2):187-191.

Phillott, A. D., R. Speare, H. B. Hines, L. F. Skerratt, E. Meyer, K. R. McDonald, S. D. Cashins, D. Mendez, and L. Berger. 2010. Minimising exposure of amphibians to pathogens during field studies. Diseases of Aquatic Organisms 92:175-185.

Ribeiro, J. S., T. Siqueira, G. L. Brejao, and E. F. Zipkin. 2018. Effects of agriculture and 
topography on tropical amphibian species and communities. Ecological Applications 28(6)1554-1564.

Sikes, R. S., W. L. Gannon, and the Animal Care and Use Committee of the American Society of Mammalogists. 2011. Guidelines of the American Society of Mammalogists for the use of wild mammals in research. Journal of Mammalogy 92:235-253.

Silver, S. C., L. E. Ostro, L. K. Marsh, L. Maffei, A. J. Noss, M. J. Kelly, R. B. Wallace, H. Gomez, and G. Ayala. 2004. The use of camera traps for estimating jaguar Panthera onca abundance and density using capture/recapture analysis. Oryx 38(2):148-154.

Sparling, D. W. 2010. Ecotoxicology of organic contaminants to amphibians. Pages 261288 in D. W. Sparling, G. Linder, C. A. Bishop, and S. K. Krest, editors. Ecotoxicology of amphibians and reptiles. CRC Press, Boca Raton, FL, USA.

Stevenson, R. D. 1985. The relative importance of behavioral and physiological adjustments controlling body temperature in terrestrial ectotherms. The American Naturalist 126(3):362-386.

Sutherland, W. J., R. Aveling, T. M. Brooks, M. Clout, L. V. Dicks, L. Fellman, E. Fleishman, D. W. Gibbons, B. Keim, F. Lickorish, and K. A. Monk. 2014. A horizon scan of global conservation issues for 2014. Trends in Ecology \& Evolution 29(1):15-22.

Tennant, E. N., B. L. Cypher, L. R. Saslaw, T. L. Westall, J. L. Mohay, E. C. Kelly, and C. L. V. H. Job. 2017. Conservation of endangered Buena Vista Lake shrews (Sorex ornatus relictus) through investigation of taxonomic status, distribution, and use of non-invasive survey methods. Wildlife Society Bulletin 44:610-616.

Treilibs, C. E., C. R. Pavey, M. N. Hutchinson, and C. M. Bull. 2016. Photographic identification of individuals of a free-ranging, small terrestrial vertebrate. Ecology and Evolution 6(3):800-809.

Welbourne, D. 2013. A method for surveying diurnal terrestrial reptiles with passive infrared automatically triggered cameras. Herpetological Review 44(2):247-250.

Welsh, H. H., and L. M. Ollivier. 1998. Stream amphibians as indicators of ecosystem stress: a case study from California's redwoods. Ecological Applications 8:11181132 .

Welsh, H. H. Jr., K. L. Pope, and D. Boiano. 2006. Sub-alpine amphibian distributions related to species palatability to non-native salmonids in the Klamath mountains of northern California. Diversity and Distributions 12:298-309.

Zhong, Y., J. Gao, Q. Lei, and Y. Zhou. 2018. A vision-based counting and recognition system for flying insects in intelligent agriculture. Sensors 18(5).

Submitted 1 March 2021

Accepted 3 May 2021

Associate Editor was K. Smith 


\section{APPENDIX I: CAMERA SETTINGS}

Camera settings used in the drift fence/camera setups deployed at Hastings Reserve, Monterey County, CA, USA, from June to August 2020. We suggest that researchers select camera settings appropriate for their project goals and consider the provided recommendations.

\begin{tabular}{|c|c|c|c|}
\hline $\begin{array}{l}\text { Broad } \\
\text { Parameter }\end{array}$ & $\begin{array}{l}\text { Subcategory } \\
\text { Parameter }\end{array}$ & Existing Setting & $\begin{array}{l}\text { Recommended Changes to } \\
\text { Settings }\end{array}$ \\
\hline \multirow[t]{2}{*}{ Camera } & Model & Reconyx HyperFire2 & \\
\hline & Focal Distance & $\begin{array}{l}\text { factory-set focal distances of } \\
50.8 \mathrm{~cm}\end{array}$ & $\begin{array}{l}\text { ensure focal distance is appro- } \\
\text { priate given the height of the } \\
\text { camera housing structure }\end{array}$ \\
\hline \multirow{6}{*}{$\begin{array}{l}\text { Trigger Set- } \\
\text { tings }\end{array}$} & Motion Sensor & On & \\
\hline & Sensitivity & Very High & \\
\hline & Photos/Trigger & 3 & $\begin{array}{l}2 \text { recommended for projects } \\
\text { with data processing con- } \\
\text { straints }\end{array}$ \\
\hline & Interval & Rapidfire & \\
\hline & Quiet Period & No Delay & $\begin{array}{l}>0 \text { for projects with data } \\
\text { processing constraints }\end{array}$ \\
\hline & Trigger Speed & $1 / 480$ th & \\
\hline \multirow{3}{*}{$\begin{array}{l}\text { Other } \\
\text { Reconyx } \\
\text { Settings }\end{array}$} & Time Lapse & Off & \\
\hline & Resolution & $1080 p$ & \\
\hline & Night Mode & Balanced, Illuminator On & \\
\hline \multirow[t]{5}{*}{ Field Set-up } & $\begin{array}{l}\text { Bucket Struc- } \\
\text { ture }\end{array}$ & $\begin{array}{l}\text { white } 7 \text {-gallon bucket; } \\
\text { wooden guideboards; acrylic } \\
\text { top with heat-reflective tape } \\
\text { and shade cloth }\end{array}$ & $\begin{array}{l}\text { bucket structure could be } \\
\text { made from more lightweight } \\
\text { and/or collapsible material, } \\
\text { such as corrugated plastic }\end{array}$ \\
\hline & Bait & bird seed and live meal worms & bait may not be necessary \\
\hline & $\begin{array}{l}\text { Temperature } \\
\text { Control }\end{array}$ & bucket only, no artificial floor & \\
\hline & Mount & $\begin{array}{l}\text { bucket; held to acrylic lid with } \\
\text { strap and duct tape }\end{array}$ & \\
\hline & Drift Fence & silt fabric, wooden stakes; $7 \mathrm{~m}$ & \\
\hline
\end{tabular}




\section{APPENDIX II: ALTERNATIVE CAMERA STRUCTURE DESIGN}

The plastic buckets used in this and other studies provide effective and durable structures for housing the cameras used in the AHDriFT system. However, they are also bulky and difficult to hike into remote field locations. We designed and built an alternative structure (Fig. 5), intended to be durable and functional but also lightweight and collapsible for convenient transport. Following recommendations of G. Lipps (pers. comm.), we also made the floor dimensions of the structure match closely with the camera's field of view. This should reduce the proportion of photos with only part of the animal visible, thereby facilitating identification by a human or a machine-learning-based tool. Finally, we addressed this system's vulnerability to vandalism and theft by adding a lock.

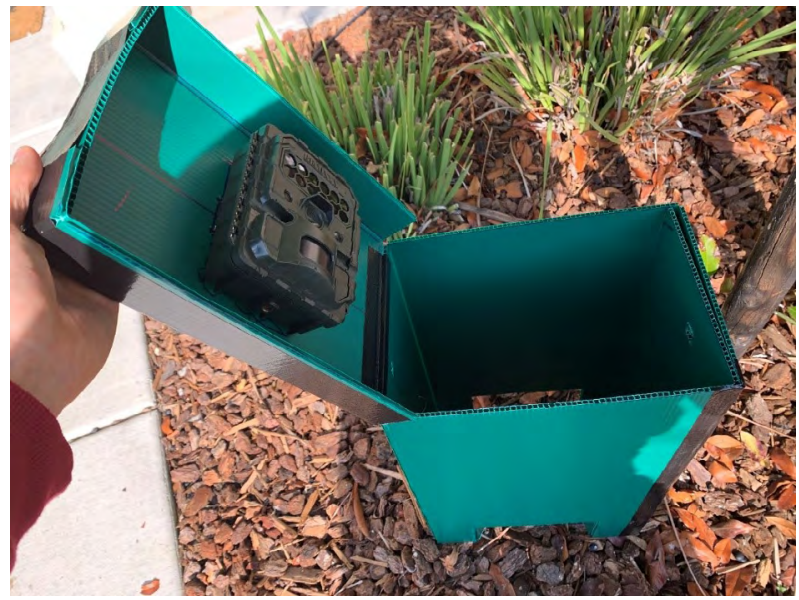

Figure 5. Alternative structure to that of Martin et al. (2017). This structure can be used in combination with a drift fence to capture images of small animals and was designed to be durable, lightweight, and collapsible.

We made the alternative structure from 4-mm thick $61 \mathrm{~cm} \mathrm{x} 122 \mathrm{~cm}$ panels of forest green corrugated plastic (SIBE-R Plastic Supply, Ocala, FL, USA), which we folded into a box shape. We cut seams along one side of the plastic sheet to allow easier folding and used duct tape where necessary to secure seams (if duct tape is not weatherproof enough for a particular project, zip ties or other materials could be used). We attached a separate piece to the top of the structure, folding edges to create a swinging lid that fits tightly. We attached the same camera model used in our study to the center of the top piece of the structure, using zip ties which we passed through the camera strap slots. The inner dimensions of the structure were $29.2 \mathrm{~cm}$ wide by $19.1 \mathrm{~cm}$ deep by $50.8 \mathrm{~cm}$ tall. We chose those width and depth dimensions because the camera's field of view was approximately the same size when the back of the camera was attached to the underside of the lid $50.8 \mathrm{~cm}$ above the ground. We opted to make the floor dimensions slightly smaller than the field of view, to further reduce the chance of an animal moving outside the field of view. For future work, we plan to reduce the focal distance of cameras to $40 \mathrm{~cm}$, which aligns with methods in McCleery et al. (2014), and we will adjust the structure dimensions accordingly. Finally, to address the structure's vulnerability to vandalism and theft, we cut holes in the sides of the structure, near the top, which allow a cable lock to be passed through the structure and the camera casing. The cable lock can then be looped around a nearby secure object, such as a tree, bush, pole, boulder, etc. (Fig. 6). As an additional advantage, this feature makes it difficult to open the lid and reveal the camera inside. 


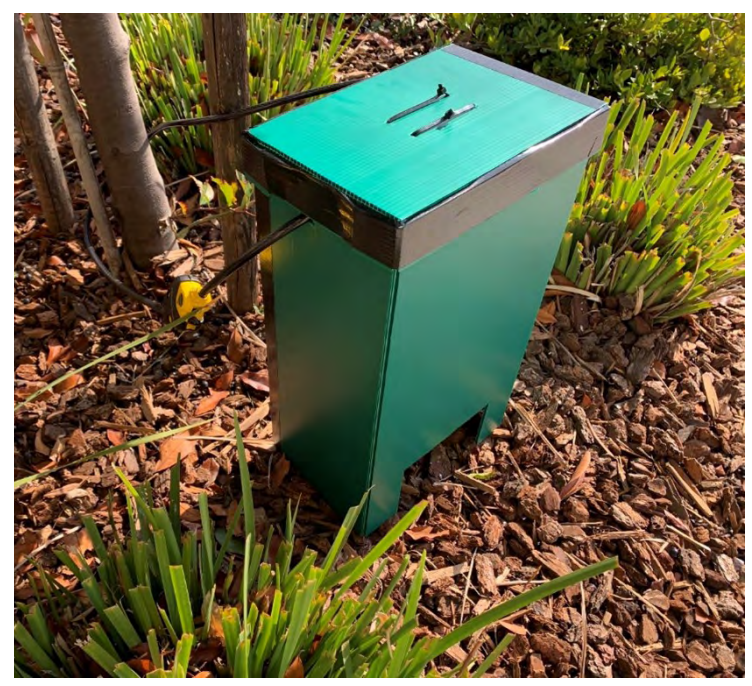

Figure 6. Alternative structure to that of Martin et al. (2017). This structure can be used in combination with a drift fence to capture images of small animals. A cable lock can be passed through openings in the sides of the structure and through the camera inside, allowing it to be locked to a nearby secure object such as a tree trunk.

This structure can be attached to the ends of drift fences by stapling the plastic to the vertical wooden stakes at the ends of the fences. The wooden guideboards can be attached in one of two ways: 1) fastening them to extra wooden stakes and pounding those stakes into the ground, so the guideboards are in the desired positions; or 2) drilling pilot holes through the guideboards and using metal tent pegs to secure them in place. In the latter option, it would be possible to provide a better attachment by also stapling the guideboards to plastic flaps left after cutting the entrance to the structure.

Researchers may consider several modifications if desired. As with the bucket design used in our study, this structure lacks a "floor," instead using bare substrate as the image background. This approach may provide a more natural and inviting environment to animals approaching the structure. However, if researchers desire an artificial floor, they can easily attach another plastic section to the bottom of the structure, which would also facilitate easier attachment of the guideboards. The color and material we used may also let in less light compared to buckets, which could result in slightly dimmer photos during daylight. Thus, researchers may consider using a lighter color of plastic if necessary (although this may make the structure more visible) or cutting openings in the plastic to let in more light. We encourage other researchers to build upon this design or experiment with designs of their own and share their results for the benefit of the greater research and management communities. 